\title{
Investigating Existence of Tourism-Led Growth Hypothesis in Cental Asian Republics: A Bootstrap Panel Causality Analysis
}

\author{
Prof. Dr. Ekrem Erdem (Erciyes University, Turkey) \\ Asst. Prof. Dr. Can Tansel Tuğcu (Nevşehir University, Turkey)
}

\begin{abstract}
The contribution of tourism to economic growth can be analyzed under the hypothesis of tourism-led growth. In this sense, this study aims at investigating the existence of the tourism-led growth hypothesis in the Turkic republics for the period 1995-2011. To this end, a bootstrap panel Granger causality analysis which was recently developed by Konya (2006) was employed. Results showed that, in a panel context, the tourism-led growth hypothesis is valid for the Turkic republics. However, the validity of this hypothesis is country specific.
\end{abstract}

\section{Introduction}

Tourism is a sector whichsupplies foreign exchange that can be used for importing capital goods for production, leading in turn to economic growth. In addition, this sector also causes convergence across countries by transferring income from developed nations to developing ones. Thus, the tourism sector can be utilizedby the policy makers either for increasing economic growth performance or reducing welfare inequalities.

The contribution of tourism to economic growth is considered underthe tourism-led growth hypothesis.According to this hypothesis, tourism can promote or cause long-run growth via its effects on the construction, transportation, accommodation, and food/beverage sectors. The tourism-led growth hypothesis is supported, if auni-directional causal relationship existsfrom tourism to economic growth. In this regard, the aim of this study is to test the existence of the tourism-led growth hypothesis in the Turkic republics (i.e. Turkey, Azerbaijan, Kazakhstan, Kyrgyz Republic and Uzbekistan)for the period 1995-2011 by employing a bootstrap panel Granger causality analysis developed by Kónya (2006).

In 2011, total international tourism receipts in the World are 1.3 trillion dollars, and 552.4 billion dollars in Europe and Central Asia. The share of international tourism receipts gained by the Turkic republics to total receipts of the World, and Europe and Central Asia are $2.53 \%$ and $5.77 \%$ respectively. Besides, the ratio of international tourism receipts to trade balance of the Turkic republics in 1995, 2000, 2005 and 2011 are 57.1\%, $131.3 \%, 214.4 \%$ and $953.4 \%$ respectively. These statistics show that tourism is so important for the economic structure of the Turkic republics in terms of income generation and financing international trade.

The rest of the paper is organized as follows: The next section reviews the literature and describes novelty. Section 3 presents the data, methodology and results. Finally, Section 4 concludes.

\section{Literature Review}

It is possible to classify the studies testing the tourism-led growth hypothesisunder two strands. The first strand is composed of the studieswhich investigate the existence of the tourism-led growth hypothesisby employing Granger causality test with time series data. Among these studies, Balaguer and Cantavella-Jorda (2002), Durbarry (2002), Dritsakis (2004), Gunduz and Hatemi-J (2005), Kim et al. (2006), Lee and Chien (2008), Brida et al. (2008), Chen and Chiou-Wei (2009), Akinboade and Braimoh (2010), Belloumi (2010), Tang and Abosedra (2012), Tang and Tan (2013) support the existence of the tourism-led growth hypothesis; whereas Oh (2005), Tang and Jang (2009), Ozturk and Acaravci (2009), and Payne and Mervar (2010)found no evidence for the validity ofthe tourism-led growth hypothesis.

Po and Huang (2008) state that time series data is not capable of reflecting the long-run relationship between tourism and economic growth in terms of coping with some diagnostic problems that arise from business cycles and structural changes, and capturing countries' characteristics. Thus, the second strand of the literature includes studies which test the tourism-led growth hypothesis by using cross-section or panel data. In this sense, Sequeira and Campos (2005), Lee and Chang (2008), Po and Huang (2008), Proenca and Soukiazis (2008), Sequeira and Nunes (2008), Falk (2010), Holzner (2011), and Lee and Brahmasrene (2013) show that there can be confusing results about the existence of the tourism-led growth hypothesisthat are sensitive to the cross-section units in consideration.

The present study as a complement to the second strand of the literature differs from the previous studies in twoaspects. First, in order to consider the possible cross-sectional dependence and heterogeneity of the sample, the panel causality analysis being employed in this study is a bootstrap panel Granger causality test recently developed by Kónya (2006). The second, to the best of our knowledge, validity of the tourism-led growth hypothesisin the Turkic republics has never been analyzed in a panel context before. Thus, the study aims to fulfill this gap and contribute to the empirical literature. 


\section{Data, Methodology and Results}

\subsection{Data}

Data set includes GDP per capita in current US\$ (GDP) and international tourism receipts in current US\$ (RCPT) for the period 1995-2011 in the Turkic republics in consideration. All the panel series were attained from World Bank, World Development Indicators database.

\subsection{Cross-Sectional Dependence}

A possible cross-sectional dependency problem in a panel analysis generally causes inconsistent and upwardbiased estimation results(Bai and Kao, 2006). Thus, it should be tested before the analysis.

This study adopts the Pesaran (2004) methodology in order to investigate the existence of the cross-sectional dependency. Pesaran (2004)proposed a cross-sectional dependency (CD) test, under the null of no cross-sectional dependence, which is asymptotically distributed as standard normal and efficient even in the panels with small sample size. This test statistic can be written in the following manner:

$$
C D=\sqrt{\frac{2 T}{N(N-1)}\left(\sum_{i=1}^{N-1} \sum_{j=i+1}^{N} \hat{p}_{i j}\right)}
$$

where $T$ is time interval, $N$ is the number of cross-section units, and $\hat{p}_{i j}$ is pair-wise correlation between cross-sections.

According to test result presented in Table 1, the null hypothesis is accepted even at $1 \%$ level of significance, indicating no cross-sectional dependence.

\begin{tabular}{|ll|}
\hline Test & Statistic \\
\hline$C D$ & $3.298(0.00)$ \\
\hline
\end{tabular}

Table 1. Cross-sectional dependence test result. (Number in parenthesis is p-value)

\subsection{Causality}

The possibility of cross-sectional dependency and heterogeneity requires a causality analysis which is capable of considering these diagnostic problems. In this regard, this study employs a bootstrap panel Granger causality analysis developed by Kónya (2006) which gives efficient results even in the panels having the cross-sectional dependency and heterogeneity problems. In the light of the tourism-led growth hypothesis, causality analysis is based on a functional relationship which can be simply formulated in the following manner:

\section{Economic Growth $=f($ Tourism $)$}

where economic growth and tourism are proxied by GDP per capita and international tourism receipts (RCPT), respectively.

The causality analysis is built on a system that contains two sets of equations which are presented below (Kónya, 2006: 981):

$$
\begin{aligned}
& y_{1, t}=\alpha_{1,1}+\sum_{l=1}^{m l y_{1}} \beta_{1,1, l} y_{1, t-1}+\sum_{l=1}^{m l x_{1}} \gamma_{1,1, l} x_{1, t-1}+\varepsilon_{1,1, t} \\
& y_{2, t}=\alpha_{1,2}+\sum_{l=1}^{m l y_{1}} \beta_{1,2, l} y_{2, t-1}+\sum_{l=1}^{m l x_{1}} \gamma_{1,2, l} x_{2, t-1}+\varepsilon_{1,2, t} \\
& \vdots \\
& y_{N, t}=\alpha_{1, N}+\sum_{l=1}^{m l y_{1}} \beta_{1, N, l} y_{N, t-1}+\sum_{l=1}^{m l x_{1}} \gamma_{1, N, l} x_{N, t-1}+\varepsilon_{1, N, t}
\end{aligned}
$$

and

$$
\begin{aligned}
& x_{1, t}=\alpha_{2,1}+\sum_{l=1}^{m l y_{2}} \beta_{2,1, l} y_{1, t-1}+\sum_{l=1}^{m l x_{2}} \gamma_{2,1, l} x_{1, t-1}+\varepsilon_{2,1, t} \\
& x_{2, t}=\alpha_{2,2}+\sum_{l=1}^{m l y_{2}} \beta_{2,2, l} y_{2, t-1}+\sum_{l=1}^{m l x_{2}} \gamma_{2,2, l} x_{2, t-1}+\varepsilon_{2,2, t}
\end{aligned}
$$




$$
x_{N, t}=\alpha_{2, N}+\sum_{l=1}^{m l y_{2}} \beta_{2, N, l} y_{N, t-1}+\sum_{l=1}^{m l x_{2}} \gamma_{2, N, l} x_{N, t-1}+\varepsilon_{2, N, t}
$$

where $y$ is real income, $x$ is international tourism receipts, $N$ is the number of cross-section units, $t$ is time interval and $l$ is the lag length. According to Kónya (2006: 981), this specification has two distinctive features. Firstly, each equation in (3), and also in (4), has different predetermined variables. The only possible link among individual regressions is contemporaneous correlation within the systems. Hence, these sets of equations are SUR systems. Secondly, since country specific bootstrap critical values are used, $y_{t}$ and $x_{t}$ are not supposed to be stationary, they denote the levels of economic growth and tourism, irrespectively of the time-series properties of these variables.

In terms of mentioned SUR systems, in country $i$ there is one-way Granger causality running from $x$ to $y$ if in (3) not all $\gamma_{1, i}$ 's are zero but in (4) all $\beta_{2, \mathrm{i}}$ 's are zero, there is one-way Granger causality from $y$ to $x$ if in (3) all $\gamma_{1, i}$ 's are zero but in (4) not all $\beta_{2, \mathrm{i}}$ 's are zero, there is two-way Granger causality between $y$ and $x$ if neither all $\beta_{2, \mathrm{i}}$ 's nor all $\gamma_{1, \mathrm{i}}$ 's are zero, and there is no Granger causality between $y$ and $x$ if all $\beta_{2, \mathrm{i}}$ 's and $\gamma_{1, \mathrm{i}}$ 's are zero (Kónya, 2006: 981).

Konya (2006) states that, since the causality test results rely critically on the lag structure, one should determine the optimal lag length. However, there is no simple rule for this purpose. Thus, as offered by Kónya (2006: 982), the present study allows different maximal lags for $y$ and $x$, but do not allow them to vary across countries. This means that altogether there are four maximal lag parameters. Assuming that their range is 1-4, Eq. (3) and (4) were estimated for each possible pair of $l y_{1}, l x_{1}$ and $l y_{2}, l x_{2}$, respectively, and the combinations which minimize the Akaike Information Criterion (AIC) were chosen.

Table 2 shows the panel causality test results. Accordingly, there exists a uni-directional and/or bi-directional causal relationships between tourism and economic growth in some of the Turkic republics. This means that, although the existence of the tourism-led growth hypothesis is proved in a panel context, it is country specific.

\begin{tabular}{|l|l|l|l|l|}
\hline \multirow{3}{*}{ Cross-Section Units } & \multicolumn{2}{|l|}{ Null hypotheses } & \multicolumn{2}{l|}{$H_{0}:$ EG does not cause RCPT } \\
\cline { 2 - 5 } & $H_{0}:$ RCPT does not cause EG & Wald & Decision \\
\cline { 2 - 5 } & Wald & Decision & 1.800 & Accept \\
\hline Turkey & $* 1.622$ & Reject & $* 11.528$ & Reject \\
\hline Azerbaijan & $* * .358$ & Reject & $* 9.612$ & Reject \\
\hline Kazakhstan & $* * 4.339$ & Reject & 1.550 & Accept \\
\hline Kyrgyz Republic & $* * 5.227$ & Reject & 1.395 & Accept \\
\hline Uzbekistan & 2.478 & Accept & \\
\hline
\end{tabular}

Table 2. Panel causality test results. **,**, and *** indicate rejection of the null hypothesis at the 1, 5, and 10 percent levels of significance, respectively.

\section{Conclusion}

This study investigates the existence of the tourism-led growth hypothesisin the Turkic republics by using annual panel data covering the period 1995-2011. The tourism-led growth hypothesis was tested by a bootstrap panel Granger causality analysis developed by Kónya (2006).

Although findings support evidence for the existence of the tourism-led growth hypothesis, it is clearly seen that the direction of causality between tourism and economic growth is found to be country specific. This result is consistent with Sequeira and Campos (2005), Lee and Chang (2008), Po and Huang (2008), Proenca and Soukiazis (2008), Sequeira and Nunes (2008), Falk (2010), Holzner (2011), and Lee and Brahmasrene (2013) who state that the validity of the tourism-led growth hypothesis is sensitive to the cross-section units in consideration.

Finally, the panel causality test results imply that investing in tourism contributes to economic growth performance of the sample in consideration. In this sense, policy makers should implement policies that subsidize tourism in order to benefit its impact on income growth.

\section{References}

- $\quad$ Akinboade, O.A., L.A. Braimoh, 2010. "International tourism and economic development in South Africa: a Granger causality test”, International Journal of Tourism Research, 12, p. 149-163.

- Bai, J., C. Kao, 2006. On the estimation and inference of a panel cointegration model with crosssectional dependence. In B. H. Baltagi (Ed.), Panel Data Econometrics: Theoretical Contributions and Empirical Applications (p.3-30). Amsterdam: Elsevier. 
- Balaguer, J., M. Cantavella-Jorda, 2002. "Tourism as a long-run economic growth factor: the Spanish case",Applied Economics,34, p. 877-884.

- Belloumi, M., 2010. "The relationship between tourism receipts, real effective exchange rate and economic growth in Tunisia”,International Journal of Tourism Research, 12, p. 550-560.

- $\quad$ Brida, J., E. Carrera, A. Risso, 2008. “Tourism's impact on long-run Mexican economic growth”,Economics Bulletin, 3(21), p. 1-8.

- Chen, C., S.Z. Chiou-Wei, 2009. “Tourism expansion, tourism uncertainty and economic growth: new evidence from Taiwan and Korea",Tourism Management, 30, p. 812-818.

- Dritsakis, N., 2004. Cointegration analysis of German and British tourism demand for Greece",Tourism Management,25, p. 111-119.

- Durbarry, R., 2002. “The economic contribution of tourism in Mauritius”,Annals of Tourism Research, 29, p. 862-865.

- Falk, M., 2010. “A dynamic panel data analysis of snow depth and winter tourism”,Tourism Management, 31(6), p. 912-924.

- Gunduz, L., A. Hatemi-J, 2005. “Is the tourism-led growth hypothesis valid for Turkey?”,Applied Economics Letters, 12(8), p. 499-504.

- Holzner, M., 2011. "Tourism and economic growth: the beach disease?", Tourism Management, 32(4), p. 922-933.

- $\quad$ Kim, H. J., M.H. Chen, S.S. Jang, 2006. "Tourism expansion and economic development: the case of Taiwan",Tourism Management, 27, p. 925-933.

- Kónya, L., 2006. "Exports and growth: Granger causality analysis on OECD countries with a panel data approach”,Economic Modelling,23, p. 978-992.

- Lee, C.C, C.P. Chang, 2008. "Tourism development and economic growth: a closer look at panels",Tourism Management, 29, p. 180-192.

- $\quad$ Lee, C.C., M.S. Chien, 2008. "Structural breaks, tourism development, and economic growth: evidence from Taiwan", Mathematics and Computers in Simulation, 77, p. 358-368.

- Lee, J.W., T. Brahmasrene, 2013. "Investigating the influence of tourism on economic growth and carbon emissions: evidence from panel analysis of the European Union",Tourism Management, 38, p. 69-76.

- $\quad$ Oh, C., 2005. "The contribution of tourism development to economic growth in the Korean economy”,Tourism Management,26(1), p. 39-44.

- Ozturk, I., A. Acaravci, 2009. "On the causality between tourism growth and economic growth: empirical evidence from Turkey”,Transylvanian Review of Administrative Sciences, 25, p. 73-81.

- $\quad$ Payne, J.E., A. Mervar, 2010. "The tourism-growth nexus in Croatia”,Tourism Economics, 19, p. 10891094.

- Pesaran, M.H.,2004. General diagnostic tests for cross section dependence in panels,Cambridge Working Papers in Economics. No: 0435, Faculty of Economics, University of Cambridge.

- Po, W.C., B.N. Huang, 2008. "Tourism development and economic growth-a nonlinear approach",Physica A: Statistical Mechanics and its Applications, 387(22), p. 5535-5542.

- Proença, S., E. Soukiazi, 2008. "Tourism as an economic growth factor: a case study for Southern European Countries",Tourism Economics, 14(4), p. 791-806.

- Sequeira, T., C. Campos,2005. "International tourism and economic growth”,Natural Resources Management, 14, p. 1-25.

- $\quad$ Sequeiraa, T.N., P.M.Nunes, 2008. "Does tourism influence economic growth? a dynamic panel data approach",Applied Economics, 40(18), p. 2431-2441.

- $\quad$ Tang, C.F., A. Abosedra, 2012. "Small sample evidence on the tourism-led growth hypothesis in Lebanon”, Current Issues in Tourism, http://dx.doi.org/10.1080/13683500.2012.732044.

- $\quad$ Tang, C.F., E.C. Tan, 2013. "How stable is the tourism-led growth hypothesis in Malaysia? evidence from disaggregated tourism markets",Tourism Management, 37, p. 52-57.

- $\quad$ Tang, C.H., S.S. Jang, 2009. “The tourism-economy causality in the United States: a sub-industry level examination",Tourism Management, 30, p. 553-558. 